\title{
STUDI DESKRIPTIF TINGKAT KEPUASAN PENGGUNA TRANSPORTASI BERBASIS ONLINE
}

\author{
Vivi Sahfitri \\ Dosen Universitas Bina Darma \\ Jalan Jenderal Ahmad Yani No.3 Palembang \\ Sur-el : vivi_sahfitri@binadarma.ac.id
}

\begin{abstract}
This study aims to conduct a descriptive study of the level satisfaction online-based transportation users viewed based on the perception by users of online transportation services. Measuring the level of satisfaction of users of online transportation services using the ServQual method provided by the driver to service users by using the variables Reliabiilty, Responsiveness, Assurance, Empathy and Tangibles. Based on the results of the study, it can be known that in each variable measured more than $50 \%$ of respondents responded to the good category of statements given related to the quality of service to users. In addition, the conclusion that can be obtained based on the results of the study is the average value of measurement shows the level of satisfaction in the category of satisfied with the quality of driver service in online-based transportation services.
\end{abstract}

Keywords: online transportation, ServQual, Satisfaction, deskriptive study

\begin{abstract}
Abstrak : Penelitian ini bertujuan untuk melakukan studi deskriptif tentang tingkat kepuasan pengguna transportasi berbasis online dilihat dari persepsi pengguna jasa transportasi online tersebut. Pengukuran tingkat kepuasan pengguna jasa trasnportasi online ini menggunakan metode ServQual atau kualitas layanan yang diberikan oleh pengemudi kepada pengguna jasa dengan menggunakan variabel Reliabilty (Keandalan), Responsiveness (daya Tanggap), Assurance (Jaminan dan Kepastian), Empathy (kepedulian) dan Tangibles (wujud fisik). Berdasarkan hasil penelitian dapat diketahui bahwa dalam setiap variabel yang diukur lebih dari 50\% responden memberikan tanggapan pada katagori baik dari pernyataan yang diberikan yang berhubungan dengan kualitas pelayanan terhadap pengguna. Selain itu kesimpuan yang dapat diperoleh dari hasil penelitian adalah nilai rata-rata pengukuran menunjukkan tingkat kepuasan pada katagori puas dengan kualitas pelayanan pengemudi pada layanan jasa transportasi berbasis online.
\end{abstract}

Kata kunci: Transportasi Online, ServQual, Kepuasan, Studi Deskriptif

\section{PENDAHULUAN}

Perkembangan dibidang Teknologi Informasi yang sangat pesat memberikan pengaruh diberbagai bidang kehidupan manusia. Dengan memanfaatkan teknologi informasi saat ini, dapat memberikan kemudahan-kemudahan bagi masyarakat dalam melakukan berbagai hal. Salah satu perubahan yang paling mendasar saat ini adalah transaksi online, dan salah satunya adalah transportasi berbasis online. Keberadaan aplikasi transportasi berbasis online ini memberikan banyak manfaat dan kemudahan bagi masyarakat luas. Penggunaan Transportasi konvensional perlahan mulai tergeser oleh transportasi berbasis online.

Transportasi online adalah pelayanan jasa transportasi yang berbasis jaringan internet dalam semua kegiatan transaksi yang dilakukannya, mulai dari pemesanan, pemnataun jalur, pembayaran, serta penilaian terhadapa layanan jasa transportasi berbasis online 
tersebut[1]. Jasa Transportasi berbasis online atau disebut dengan istilah aplikasi Ridesharing mulai ramai keberadaannya di Indonesia tahun 2014 yang dimulai dengan kemunculan uber Taxi sebagai bisnis layanan transportasi berbasis online yang kemudian diikuti oleh kemunculan aplikasi transportasi berbasis online lainnya seperti Gojek, Grab, Maxim dan lain-lain.

Pada dasarnya keberadaan jasa transportasi berbasis online diawali dengan munculnya smartphone sebagai alat komunikasi yang semakin berkembang pesat. Dengan smartphone semua hal dapat dilakukan dalam genggaman tangan. Jika pada awalnya untuk menggunakan jasa taksi ataupun ojek, pelanggan harus kepangkalan atau menunggu jika ada taksi atau ojek yang lewat atau menghubungi ke customer service taksi [2], tetapi saat ini hal tersebut sangat mudah dilakukan dengan hanya melakukan transaksi online menggunakan smartphone maka jasa transportasi yang kita butuhkan akan menjemput dan siap mengantarkan kita ketempat tujuan tanpa perlu bernegosiasi harga seperti pada transportasi konvesional. Kemudahan penggunaan transportasi berbasis online menyebabkan mulai beralihnya kebutuhan akan jasa transportasi pada masyarakat dari jasa transportasi konvensional.

Semakin maraknya jasa transportasi online memberikan banyak pilihan bagi masyarakat untuk menggunakan jasa transportasi online yang memberikan kepuasaan terhadapat pelayanan yang diberikan kepada pelanggan yang menggunakan jasa transportasi berbasis online tersebut. Kepuasan sendiri merupakan perasaan senang atau kecewa seseorang yang diperoleh dari pelayanan yang diperolehnya. Kepuasan merupakan perbandingan antara kesan seseorang terhadap kinerja atau hasil suatu produk baik jasa maupun barang dengan apa yang diharapkannya. Pelayanan yang sebaikbaiknya kepada konsumen merupakan salah satu upaya untuk memperoleh penilaian yang tinggi dari konsumen. Banyak hal yang dapat menjadi faktor ukuran kepuasan konsumen antara lain, nilai total konsumen yang terdiri dari nilai produk, nilai pelayanan, nilai personal, nilai image atau citra, dan nilai biaya total konsumen yang terdiri dari biaya moneter, biaya waktu, biaya tenaga dan biaya pikiran [3].

Penelitian ini bertujuan untuk menganalisis tingkat kepuasan para pengguna jasa transportasi berbasis online. Kepuasan sebagai sikap yang didasarkan pada pengalaman yang didapat [4], merupakan penilaian mengenai ciri atau keistimewaan produk, jasa atau produk itu sendiri[5], yang menyajikan tingkat kesenangan konsumen terkait dengan pemenuhan kebutuhan konsumsi. Salah satu faktor yang mempengaruhi tingkat kepuasan pelanggan adalah kualitas pelayanan ( Service Quality). Konsep kualitas layanan dapat diartikan sebagai suatu daya tanggap dan realitas dari jasa yang diberikan oleh sebuah perusahaan. Kualitas layanan diawali dengan kebutuhan dari customer dan berujung pada persepsi Customer[3]. Hal ini membuktikan bahwa kualitas bukan dilihat dari persepsi penyedia layanan jasa atau perusahaan, akan tetapi didasarkan pada persepsi atau anggapan pelanggan. 
Pengukuran tingkat kepuasan pengguna pada penelitian ini menggunakan model ServQual yang mennggunakan lima indikator didalamnya, yaitu[6]: 1) Reliability (Keandalan), 2)Responsiveness (Daya Tanggap), 3) Assurance (Jaminan dan Kepastian), 4) Emphaty (Kepedulian), dan 5) Tangible (Wujud Fisik).

\section{METODOLOGI PENELITIAN}

Metode penelitian merupakan tahapn atau langkah-langkah ilmiah yang digunakan untuk memperoleh data untuk digunakan dengan tujuan atau kegunaan tertentu. Metode Penelitian Secara umum Metode penelitian menyajikan cara sistematis yang digunakan pada kegiatan penelitian dengan tujuan untuk mencari pemecahan terhadap suatu masalah [7].

Penelitian ini menggunakan metode Penelitian Deskriptif yaitu metode penelitian yang bertujuan untuk menemukan pengetahuan seluas-luasnya terhadap objek yang digunakan pada penelititian pada masa tertentu [8]. Penelitian deskriptif bukan menguji hipotesis, akan tetapi mendeskripsikan peristiwa atau kejadian yang mejadi perhatian tanpa memberikan perlakukan khusus pada peristiwa tersebut [9].

\subsection{Metode Pengumpulan Data}

Metode pengumpulan data untuk studi deskriptif dalam pennelitian ini adalah dengan menggunakan metode Non Probability dengan Purposive Random Sampling ( Sampling Pertimbangan) merupakan salah satu teknik sampling yang digunakan jika dalam penelitian, peneliti memiliki pertimbangan - pertimbangan tertentu dalam memilih sampelnya untuk mencapai tujuan tertentu [10]. Metode Purposive Random Sampling dilakukan dengan cara menetapkan responden sebagai sample penelitian didasarkan pada anggapan bahwa responden yang menjadi inforamn akan memberikan data yang lengkap, tepat dan akurat. Pada teknik Purposive Tandom Sampling semua sampel memiliki peluang yang sama tidak dipengaruhi dan tidak terikat dengan apa pun untuk menjadi sampel penelitian.

\subsection{Sumber Data}

Data yang digunakan dalam penelitian ini adalah data primer yang diperoleh langsung dari sumber data tanpa melalui perantara [11]. Data primer diperoleh melalui kuisioner yang disebarkan melalui secara online melalui google form kepada responden yang menjadi objek penelitian. Data mentah yang diperoleh dari hasil pegisian kuisioner yang dilakukan responden akan dianalisis secara deskriptif. Tahapan yang dilakukan dalam analisis deskriptif adalah tahap verifikasi, pengorganisasian data, trasnformasi data, Penggabungan data, pengurutan data, perhitungan data, dan ekstraksi data untuk membentuk informasi dan pengetahuan [12]. Selain data primer, dalam penelitia ini juga membutuhkan data sekunder untuk mendeskripsikan hasil dari data primer yang diperoleh. Data sekunder merupakan data yang bersumber dari berbagai literature dan penelitian sebelumnya yang dilakukan dan dicatat oleh pihak lain [13]. 


\subsection{Sample dan Instrumen Penelitian}

Penelitian ini menggunakan sampel penelitian sebanyak 87 responden yang telah mengisi kuisoner melalui google form yang ada dengan melihat kebenaran dari data yang diberikan dan sesuai dengan petunjuk pengisian.

Sedangkan instrument atau alat penelitian yang digunakan adalah kuisioner, yaitu suatu alat penelitian untuk mengukur fenomena alam maupun social yang diamati [14]. Pertanyaan dalam Kuisioner yang digunakan bertipe tertutup. Pertanyaan bertipe tertutup dapat membantu responden lebih mudah menentukan jawaban dengan cepat karena pilihan jawbaan sudah tersedia dalam kuisioner [15].

\subsection{Operasional Variabel}

Variabel yang digunakan dalam penelitian ini mengadopis variable yang dikemukakan oleh Zeithaml dan Bitner [6], Deskripsi dari operasioan variable yang digunakan dalam penelitian dapat dilihat pada tabel 1 .

Tabel 1. Variabel Penelitian

\begin{tabular}{ll}
\hline \multicolumn{1}{c}{ Variabel } & \multicolumn{1}{c}{ Dimensi } \\
\hline $\begin{array}{l}\text { Reliability } \\
\text { (Keandalan) }\end{array}$ & - Kecepatan Pengemudi dalam \\
& melayani pelanggan \\
& - Prosedur pelayanan tidak \\
& berbelit-belit \\
& - Pelayanan yang memuaskan \\
& - Tanggap terhadap keluhan \\
Responsiveness & pelanggan \\
(Daya Tanggap) & - Kesediaan Pengemudi \\
& membantu pelanggan \\
& - Kecepatan dalam \\
& menyelesaikan masalah \\
Assurance & Keramahan dalam melayani \\
(Jaminan dan & pelanggan \\
Kepastian) & - Pengetahuan yang luas \\
& - Keamanan pelanggan terjamin \\
$\begin{array}{l}\text { Emphaty } \\
\text { (Kepedulian) }\end{array}$ & - Tersedia layanan 24 jam \\
& - Mengetahui keinginan \\
& pelanggan
\end{tabular}

- Mampu berkomunikasi dengan baik

- Kendaraan dan interior yang

Tangible bagus dan menarik

(Wujud Fisik) - Kebersihan dan kenyamanan

- Kelengkapan fasilitas yang ditawarkan

- Kebersihan dan kerapian Pengemudi

\subsection{Analisis data}

Data yang diperoleh dari kegiatan penelitian di analisis dengan menggunakan teknik analisis data kualitatif yang terdiri dari tiga kegiatan yaitu; Reduksi data yaitu proses pemilihan, pemusatan perhatian pada penyederhanaan, pengabstrakan dan transformasi data “ kasar" yang muncul dari catatan-catatan tertulis dilapangan, Penyajian data yaitu presentasi data yang dapat berbentuk Matrik, Grafik, Jaringan atau Bagan, dan penarikan kesimpulan atau verifikasi yaitu hasil akhir dari kegiatan penelitian yang diperoleh dari sekumpulan informasi yang sudah dihasilkan[16].

\section{HASIL DAN PEMBAHASAN}

\subsection{Deskripsi Responden}

Responden yang terlibat dalam penelitian ini berasal dari berbagai individu. Jumlah responden yang mengisi kuisioner berjumlah 87 responden dengan rincian seperti terlihat pada tabel 2, 3, 4, dan 5 .

Tabel 2. Deskrispi Responden Berdasarkan

\begin{tabular}{lcc}
\multicolumn{3}{c}{ Jenis Kelamin } \\
\hline \multicolumn{1}{c}{ Jenis Kelamin } & Jumlah & $\%$ \\
\hline Laki-laki & 24 & 28 \\
Perempuan & 63 & 72 \\
Jumlah & 87 & 100 \\
\hline
\end{tabular}

\begin{tabular}{ccc} 
Jumlah & 87 & 100 \\
\hline Berdasar tabel 2 dapat diketahui bahwa
\end{tabular}

jumlah responden laki-laki sebanyak 24 responden atau $28 \%$ sedangkan jumlah 
responden perempuan sebanyak 63 atau $72 \%$ dari total keseluruhan responden penelitian. Komposisi reponden berdasarkan jenis kelamin terebut menunjukkan bahwa penggunan jasa transportasi online lebih banyak perempuan. Hal ini sejalan dengan penelitian yang dilakukan oleh Aspiani [17] yang menyebutkan bahwa 89\% dari 100 responden pengguna jasa Transportasi Online adalah perempuan. Salah satu faktor dari kondisi tersebut adalah rasa aman, kecepatan dan ketepatan waktu yang dirasakan oleh Pengguna Transportasi Online tersebut.

Tabel 3. Deskrispi Responden Berdasarkan

\begin{tabular}{lcc}
\multicolumn{3}{c}{ Usia } \\
\hline \multicolumn{1}{c}{ Usia } & Jumlah & \% \\
\hline$\leq 20$ tahun & 13 & 15 \\
$21-30$ tahun & 26 & 30 \\
$31-40$ tahun & 33 & 38 \\
$>$ 40 tahun & 15 & 17 \\
Jumlah & 87 & 100 \\
\hline
\end{tabular}

Berdasarkan tabel 3, usia pengguna jasa transportasi online cukup bervariasi. Dari data yang diperoleh usia pengguna jasa Transportasi online terbanyak adalah pada usia 31-40 tahun. Namun dari pada dasarnya pengguna jasa transportasi online cukup merata di berbagai tingkatan usia. Penelitian yang dilakukan oleh Yovan Sawir Saputra dan Shinta Wahyu Hati [18] memberikan hasil bahwa pengguna jasa transportasi online terbanyak adalah ditingkatan usia 17-26 tahun.

\section{Tabel 4. Deskrispi Responden Berdasarkan} Pekerjaan

\begin{tabular}{lcc}
\hline \multicolumn{1}{c}{ Pekerjaan } & Jumlah & \% \\
\hline Pelajar/Mahasiswa & 27 & 31 \\
Pegawai/Karyawan & 35 & 40 \\
Wiraswasta & 16 & 18 \\
Lain-Lain & 9 & 10 \\
Jumlah & 87 & 100 \\
\hline \multicolumn{2}{c}{ Pengguna jasa transportasi onlien yang }
\end{tabular}

Pengguna jasa transportasi onlien yang paling banyak adalah berprofesi sebagai Pegawai/ karyawan baik di instansi pemerintah maupun swasta. Dari hasil pengolahan data penelitian dari 87 responden yang mengisi kuisioner dapat diketahui bawhwa $40 \%$ atau 35 orang responden adalah pegawai/ karyawan sedangka sisanya berprofesi sebagai Pelajar/mahasiswa, wiraswasta serta profesi lainnya.

Tabel 5. Deskrispi Responden Berdasarkan Intensitas Penggunaan Transportasi Online dalam sebulan

\begin{tabular}{lcc}
\hline \multicolumn{1}{c}{ Intensitas } & Jumlah & \% \\
\hline$\leq 5$ & 27 & 31 \\
$6-10$ & 21 & 24 \\
$11-20$ & 25 & 29 \\
$>20$ & 14 & 16 \\
Jumlah & 87 & 100 \\
\hline
\end{tabular}

Intensitas atau tingkat keseringan dalam menggunakan jasa transportasi online dalam sebulan cukup bervariasi. Berdasarkan tabel 5 dapat diketahu bahwa responden penelitian menggunakan jasa transportasi online antara 1-5 berjumlah $31 \%$ dari 87 oang responden. Namun pada dasarnya, intensitas penggunaaan jasa transportasi online ini menyebar dengan baik mulai dari tingkat intensitas terendah sampai tertinggi dalam ukuran yang digunakan dalam penelitian ini memiliki jumlah persentase yang tidak jaug berbeda. Sehingga dapat disimpulan bahwa penggunaan jasa transportasi online ini sangat sering digunakan oleh pelanggannya.

\subsection{Deskripsi Variabel}

Variabel Penelitian ini dikelompokkan menjadi Reliability (Keandalan), Responsiveness (Daya Tanggap), Assurance (Jaminan dan Kepastian), Emphaty (Kepedulian), Assurance (Jaminan dan Kepastian dan Wujud (Fisik). Berikut hasil penelitian dari masing masing variabel yang digunakan. 


\section{a. Variabel Reliability (Keandalan)}

Berdasarakan data yang diperoleh dari penyebaran kusioner, maka hasil yang diperoleh untuk variabel Reliability dapat dilihat pada tabel 6.

Tabel 6. Deskrispi Variabel Reliability

\begin{tabular}{llcc}
\hline \multicolumn{1}{c}{ Pernyataan } & $\begin{array}{c}\text { Alternatif } \\
\text { Jawaban }\end{array}$ & $\boldsymbol{F}$ & \% \\
\hline Kecepatan & Sangat Cepat & 45 & 52 \\
Pengemudi dalam & Cepat & 39 & 45 \\
melayani & Cukup Cepat & 3 & 3 \\
pelanggan & Lambat & 0 & 0 \\
Prosedur & Sangat Efisien & 42 & 48 \\
pelayanan tidak & Efisien & 40 & 46 \\
berbelit-belit & Cukup efisien & 5 & 6 \\
Pelayanan & Tidak Efisien & 0 & 0 \\
memuaskan & Sangat Puas & 38 & 44 \\
& Puas & 43 & 49 \\
& Cukup Puas & 6 & 7 \\
\multicolumn{2}{c}{ Berdasarkan Tabel 6 diperoleh } & fakta
\end{tabular}

dalam penelitian bahwa pada variabel reliability (keandalan) responden memberikan pendapat denga tingkat pengukuran yang tinggi bagi setiap indikator pada variabel reliability. Kepuasan responden penelitian pada pernyataan kecepatan Pengemudi dalam melayani pelanggan memberikan tanggapan paling banyak pada alternative jawaban sangat cepat yaitu 52\%, tanggapan cepat sebanyak $45 \%$ dan hanya $3 \%$ yang memberikan tanggapan cukup. Tidak ada yang memberikan tanggapan lambat dalam kecepatan Pengemudi melayani pelanggan ini.

Tanggapan yang diberikan responden yang berhubungan dengat prosedur pelayanan transportasi berbasis online sangat baik. $48 \%$ responden berpendapat bahwa prosedur pelayanan dalam menggunakanjasa transportasi online tidak berbelit-belit dan sangat efisien dan $46 \%$ memberikan tanggapan efisien serta hanya $6 \%$ yang memberi tanggapan cukup. Tidak ada yang memberikan tanggapan bahwa Prosedur pelayanan jasa transportasi online tidak efisien atau berbelit-belit.

Pada variabel Realibility ini secara keseluruhan responden memberikan tanggapan puas tentang pelayanan terhadapa konsumen sebesar 49\%, namun yang memberikan tanggapan sangat puas juga cukup banyak yaitu $44 \%$ yang hanya berselisih 5\% dengan tanggap puas yang diberikan responden. 7\% Responden memberikan tanggapan cukup puas dan tidak ada yang memberikan tanggapan tidak puas terhadap pelayanan jasa Transportasi online.

Dari tanggapan yang diberikan untuk variabel Realiability dapat diketahui bahwa responden penelitian yang menjadi pengguna jasa transportasi online memberikan respon baik terhadap keandalan dari jasa transportasi online yang mereka gunakan. Perbedaaan tingkat respon yang diberikan merupakan gambaran kepuasan yang diterima pelanggan. Perbedaan respon ini bisa disebabkan oleh berbagai hal antara lain Personal Pengemudi atau pelanggan sendiri, aplikasi yang digunakan serta kondisi lapangan saat menggunakan jasa transportasi online ini.

\section{b. Variabel Responsiveness (Daya Tanggap)}

Tabel 7 menampilkan hasil pengolahan data yang diperoleh dari penyebaran kusioner untuk variabel Responsiveness (Daya Tanggap).

Tabel 7. Deskrispi Variabel Responsiveness

\begin{tabular}{llcc}
\hline Pernyataan & \multicolumn{1}{c}{$\begin{array}{c}\text { Alternatif } \\
\text { Jawaban }\end{array}$} & $\boldsymbol{F}$ & \% \\
\hline Tanggap & Sangat Tanggap & 34 & 39 \\
terhadap & Tanggap & 39 & 45 \\
keluhan & Cukup & 14 & 16 \\
pelanggan & Tidak Tanggap & 0 & 0 \\
Kesediaan & Sangat membantu & 39 & 45 \\
Pengemudi & Membantu & 32 & 37
\end{tabular}




\begin{tabular}{llcc} 
membantu & Cukup Membantu & 16 & 18 \\
pelanggan & Tidak Membantu & 0 & 0 \\
Kecepatan & Sangat Puas & 31 & 36 \\
dalam & Puas & 35 & 40 \\
menyelesaikan & Cukup Puas & 21 & 24 \\
masalah & Tidak Puas & 0 & 0 \\
\hline \multicolumn{1}{c}{ Hasil } & Pengolahan data & pada & variabel
\end{tabular}
responsiveness dapat dilihat pada tabel 7. Dari hasil penyebaran kuisioner diperoleh fakta penelitian bahwa $39 \%$ responden memberikan pendapat bahwa jasa transportasi berbasis online sangat tanggap dalam menanggapi keluhan pelanggan, $45 \%$ memberikan pendapat tanggap, $16 \%$ memberikan pendapat cukup tanggap. Tidak ada responden yang memberikan jawaban tidak tanggap terhadap pernyataan tentang tanggapan terhadap keluhan pelanggan.

Tanggapan terhadap kesediaan Pengemudi membantu pelanggan berdasarkan hasil kuisioner diperoleh fakta bahwa $45 \%$ responden memberikan tanggapan Pengemudi sangat membantu, $37 \%$ responden memilih jawaban membantu dan $18 \%$ memilih jawaban cukup membantu dan tidak ada yang memberikan jawaban tidak membantu. Hal ini menunjukan secara keseluruhan Pengemudi jasa transportasi online bersedia membantu pelanggannya.

Untuk pernyataan kecepatan dalam penyelesaian masalah diperoleh fakta penelitian $36 \%$ memberikan tanggapan sangat puas, $40 \%$ memberikan tanggapan Puas dan 24\% memberikan tanggapan cukup puas. Hal ini memberikan fakta bahwa Pengemudi jasa transportasi online dapat memberikan solusi cepat untuk permasalahan yang timbul. Salah satu masalah yang sering ditemui adalah kesalahan dalam menentukan alamat penjemputan ataupun tujuan. Tidak ada yang memberikan tanggapan tidak puas atas kecepatan dalam penyelesaian masalah saat menggunakan jasa transportasi online.

Untuk Variabel Responsiveness, responden secara keseluruhan memberikan tanggapan yang baik serta tidak ada yang mebrikan tanggapan yang tidak baik. Hal ini memberikan fakta pengguna jasa transportasi online merasa puas terhadap daya tanggap yang diberikan pengemudi selama transaksi berlangsung. Respon terhadap keluhan pelanggan, kecepatan dan kesediaan pengemudi membantu pelanggannya memberikan tingkat kepuasan yang tinggi pada pelanggan. Hal ini juga sejalan dengan penelitian yang dilakukan oleh Erlin Setyaningsih, dkk [19] yang memberikan hasil penelitian tingkat kepuasan pengguna jasa transportasi Online di Balikpapan dengan menggunakan metode PIECES yang memberikan hasil bahwa tingkat kepusana konsumen berada pada katagori Puas.

c. Variabel Assurance (Jaminan \& Kepastian)

Pengolahan data kuisioner untuk variabel Assurance (Jaminan dan Kepastian) dapat dilihat pada tabel 8 berikut.

Tabel 8. Deskrispi Variabel Assurance

\begin{tabular}{llcc}
\hline \multicolumn{1}{c}{ Pernyataan } & \multicolumn{1}{c}{$\begin{array}{c}\text { Alternatif } \\
\text { Jawaban }\end{array}$} & $\boldsymbol{F}$ & \% \\
\hline $\begin{array}{l}\text { Keramahan } \\
\text { dalam }\end{array}$ & Sangat Ramah & 36 & 41 \\
melayani & Ramah & 38 & 44 \\
pelanggan & Cukup Ramah & 11 & 13 \\
Pengetahuan & Tidak Ramah & 2 & 2 \\
yang luas & Sangat Mudah & 27 & 31 \\
& Berkomunikasi & & \\
& Mudah & 34 & 39 \\
& Berkomunikasi & & \\
& Cukup Mudah & 19 & 22 \\
& Berkomunikasi & & \\
& Tidak Suka & 7 & 8 \\
Berkomunikasi & & \\
Keamanan & Sangat Terjamin & 42 & 48 \\
pelanggan & Terjamin & 45 & 52 \\
terjamin & Cukup Terjamin & 0 & 0 \\
& Tidak Terjamin & 0 & 0 \\
\hline
\end{tabular}


Berdasarkan Tabel 8 diperoleh fakta dari hasil penelitian pada variabel Assurance bahwa sebesar $41 \%$ responden memberikan tanggapan sangat ramah pada pengukuran indikator keramahan Pengemudi transportasi online dalam melayani pelanggan, $44 \%$ memilih jawaban ramah saja, 13\% memilih jawaban cukup ramah dan $2 \%$ memilih jawaban tidak ramah. Bervariasinya jawaban dari pernyataan yang diberikan bisa dikarenakan karakteristik kepribadian yang berbeda dari Pengemudi yang pernah melayani pengguna jasa transportasi online tersebut.

Selain keramahan yang diberikan oleh pengemudi (Pengemudi), variabel Assurance juga berkaitan dengan keluasan pengetahuan yang dimiliki Pengemudi. Hal ini juga menjadi faktor mudah atau tidaknya Pengemudi berkomunikasi dengan pelanggannya selama pengguna jasa transportasi online tersebut berlangsung. Dari hasil pengolahan data kuisioner diperoleh fakta bahwa $31 \%$ pengemudi Transportasi online sangat mudah berkomunikasi dengan pelanggannya, 39\% responden memilih jawaban Mudah berkomunikasi, 22\% memilih Cukup mudah berkomunikasi dan ada $8 \%$ yang memilih jawaban bahwa pengemudi tidak suka berkomunikasi. Sedangkan untuk indikator keamanan pelanggan responden memberikan jawaban sangat terjamin sebesar $48 \%$ dan jawaban terjamin saja sebesar $52 \%$. Hal ini dapat diartikan bahwa pelanggan merasa sangat aman dan nyaman menggunakan jasa Transportasi Online.

Berdasarkan hasil yang diperoleh dapat diketahui bahwa secara keseluruhan respon yang diberikan pelanggan untuk variabel Assurance (Jaminan dan Kepastian) berada pada kategori Baik. Meskipun ada beberapa reponden yang memberikan jawaban tidak baik untuk pernyataan keramahan dalam melayani pelanggan dan pengetahuan yang luas, namun jumlahnya tidak terlalu besar. Faktor yang dapat mempengaruhi respon tidak baik dari pelanggan antara lain sikap dan sifat pengemudi yang kurang baik, artinya variabel ini bergantung dari individu masing masing pengemudi untuk dapat memberikan pelayan yang baik pada pelanggannya.

\section{d. Variabel Emphaty (Kepedulian)}

Hasil pengolahan data untuk variabel Emphaty (Kepedulian) dapat dilihat pada tabel 9 berikut.

Tabel 9. Deskrispi Variabel Emphaty

\begin{tabular}{llcc}
\hline \multicolumn{1}{c}{ Pernyataan } & $\begin{array}{c}\text { Alternatif } \\
\text { Jawaban }\end{array}$ & $\boldsymbol{F}$ & $\boldsymbol{\%}$ \\
\hline Tersedia & Tersedia & 6 & 7 \\
layanan 24 jam & Tidak Tersedia & 81 & 93 \\
Mengetahui & Sangat Perduli & 28 & 32 \\
keinginan & Perduli & 35 & 40 \\
pelanggan & Cukup Perduli & 22 & 25 \\
& Tidak Perduli & 2 & 2 \\
Mampu & Sangat Baik & 26 & 30 \\
berkomunikasi & Baik & 31 & 36 \\
dengan baik & Cukup Baik & 22 & 25 \\
& Tidak Baik & 8 & 9 \\
\hline \multicolumn{1}{c}{ Tabel } & mal
\end{tabular}

Tabel 9 merupakan hasil pengolahan data untuk variabel Emphaty. Hasil tabulasi data berdasarkan hasil kuisioner yang telah diisi oleh responden diperoleh fakta bahwa $93 \%$ responden menyatakan bahwa transportasi online tidak memberikan layanan 24 jam, sedangkan hanya $7 \%$ yang memberikan jawaban bahwa transportasi online memberikan layanan 24 jam. Kondisi ini dapat terjadi karena para driver transportasi online tidak beraktifitas terutama dimalam hari karena faktor keamanan. Selain itu 
jumlah pengguna jasa Transportasi online di malam hari terutama pada pukul 00.00 keatas tidak begitu banyak. Tindak kejahatan yang semakin banyak khususnya pada pengemudi jasa transportasi online menjadi faktor lain yang menyebabkan sulitnya menncari jasa transportasi online di malam hari.

Pada pernyataan yang berkaitan dengan kepedulian pengemudi tentang keinginan pelanggan, responden memberikan tanggapan sebesar $32 \%$ untuk pilihan jawaban sangat perduli, $40 \%$ untuk pilihan Perduli, 25\% untuk pilihan cukup perduli dan $2 \%$ responden memilih jawaban tidak perduli. Sedangkan untuk pernyataan kemampuan berkomunikasi pengemudi, responden memberikan tanggapan $30 \%$ memilih sangat baik, 36\% memilih Baik, 25\% memilih Cukup Baik dan 9\% memilih jawaban tidak baik. Adanya respon tidak baik terhadap kepedulian dan kemampuan komnikasi yang dimiliki pengemudi bisa disebabkan oleh faktor personal atau sifat dari pengemudi yang secara psikologis merupakan individu yang introvert atau pendiam. Sehingga tidak mudah untuk diajak berbicara selama dalam perjalanan menggunakan jasa transportasi online. Akan tetapi selama pelayanan yang diberikan oleh pengemudi baik maka hal-hal yang tersebut dapat diatasi dan pelanggan akan tetap memberikan respon yang baik.

\section{e. Variabel Tangible (Wujud Fisik)}

$$
\text { Variabel ini berkaitan dengan fisik }
$$

kendaraan sebagai sarana utama pada jasa transportasi online. Tabel 10 menunjukkan hasil pengilahan data kuisioner pada variabel Tangible (wujud Fisik).
Tabel 10. Deskrispi Variabel Tangible

\begin{tabular}{|c|c|c|c|}
\hline Pernyataan & $\begin{array}{c}\text { Alternatif } \\
\text { Jawaban }\end{array}$ & $F$ & $\%$ \\
\hline \multirow{8}{*}{$\begin{array}{lr}\text { Kendaraan } & \text { dan } \\
\text { interior yang } \\
\text { bagus } \\
\text { menarik } \\
\text { Kebersihan dan } \\
\text { kenyamanan }\end{array}$} & Sangat Baik & 31 & 36 \\
\hline & Baik & 28 & 32 \\
\hline & Cukup Baik & 22 & 25 \\
\hline & Tidak Baik & 6 & 7 \\
\hline & Sangat Baik & 37 & 43 \\
\hline & Baik & 40 & 46 \\
\hline & Cukup Baik & 10 & 11 \\
\hline & Tidak Baik & 0 & 0 \\
\hline \multirow{4}{*}{$\begin{array}{l}\text { Kelengkapan } \\
\text { fasilitas yang } \\
\text { ditawarkan }\end{array}$} & Sangat Baik & 27 & 31 \\
\hline & Baik & 35 & 40 \\
\hline & Cukup Baik & 21 & 24 \\
\hline & Tidak Baik & 4 & 5 \\
\hline \multirow{4}{*}{$\begin{array}{l}\text { Kebersihan dan } \\
\text { kerapian }\end{array}$} & Sangat Baik & 37 & 43 \\
\hline & Baik & 42 & 48 \\
\hline & Cukup Baik & 8 & 9 \\
\hline & Tidak Baik & 0 & 0 \\
\hline
\end{tabular}

Berdasarkan tabel 10 dapat diketahui

bahwa pada variabel tangibles alternatif jawaban yang dipih dari pernyataan yang diberikan dalam kuisioner adalah pada jawaban sangat baik dan baik, walaupun ada responden yang memberikan jawaban selain itu. Pada pernyataan kendaraan dan interior yang bagus dan menarik sebesar $36 \%$ responden menyatakan sangat baik, $32 \%$ menyatakana Baik saja, 25\% menyatakan cukup baik dan sebesar 7\% responden memilih jawaban tidak baik. Beberapa jasa Transportasi online membatasi kendaraan yang digunakan untuk kurun waktu tertentu, misalnya hanya kendaraan yang berumur 5 tahun ke atas yang diperbolehkan. Namun pada kenyataannya, kendaraan yang diperoleh tidak sesuai dengan identitas saat memesan. Hal ini menjadi pemicu pelanggan mengkomplain jasa yang diperolehnya. Kondisi tersebut dapat menjadai salah satu faktor ketidakpuasan pelanggan terhadap kendaraan yang dipesannya.

Pernyataan tentang kebersihan dan kenyamanan kendaraan diperoleh hasil $43 \%$ responden menyatakan sangat baik, $46 \%$ menyatakan baik dan $11 \%$ memberikan respon 
cukup baik serta tidak ada responden yang memberikan tanggapan tidak baik. Respon terhadap Pernyataan kelengkapan dan fasilitas kendaraan menunjukkan sebesar $32 \%$ memberikan respon Sangat baik, $40 \%$ memberikan respon baik, 24\% memberikan respon Cukup baik dan 5\% responden memilih memberikan respon tidak baik. Sedangkan untuk pernyataan kebersihan dan kerapian diperoleh fakta sebesar $43 \%$ responden memilih jawaban sangat baik, $48 \%$ memilih jawaban baik dan $9 \%$ memilih jawaban Cukup baik dan tidak ada yang memilih jawaban tidak baik.

Secara keseluruhan respon yang diberikan untuk variabel Tangibles baik yang artinya pelanggan Puas dengan layanan yang mereka peroleh khususnya dengan kendaraan yang mereka pesan untuk jasa transportasi online ini. Kalau pun ada responden yang memberikan jawaban tidak baik terutama pada pernyataan fasilitas, hal tersebut hanya sebagian kecil dan biasanya hampir semua kendaraan jasa transportasi online melengkapi fasilitas estándar kendaraan seperti AC, Tisu serta beberapa pengemudi menyediakan permen atau air mineral cup di kendaraannya.

\section{KESIMPULAN}

Berdasarkan hasil yang telah diperoleh dari pelaksanaan penelitian, maka dapat disimpulkan hal-hal berikut;

1. Hasil analisis data yang diperoleh dari responden untuk setiap variabel dalam penelitian menunjukkan respon yang baik terhadap jasa transportasi online yang digunakan. Dari semua variabel yang diukur dapat disimpulkan bahwa tingkat kepuasan pelanggan transportasi online berada pada katagori Puas. Yang ditabulasikan secara keseluruhan nilai tingkat kepuasan tersebut adalah sangat puas dengan nilai rata-rata 5.20, Puas dengan nilai rata-rata 5.56, Cukup Puas dengan rata rata nilai 1.97 dan tidak puas dengan nilai rata rata 0.29 .

2. Faktor - faktor yang dapat mempengaruhi ketidakpuasan pelanggan antara lain adalah identitas kendaraan yang berbeda, komunikasi dan pelayan yang kurang baik. Hal ini dapat menjadi masukkan bagi penyedia jasa transportasi online umumnya dan pengemudi khususnya untuk terus meningkatkan pelayanan kepada pengguna jasanya agar dapat terus bertahan disaat semakin banyaknnya penyedia jasa sejenis

\section{DAFTAR PUSTAKA}

[1] Pratama, Geistiar Yoga, and Aminah Suradi. "Perlindungan Hukum Terhadap Data Pribadi Pengguna Jasa Transportasi Online Dari Tindakan Penyalahgunaan Pihak Penyedia Jasa Berdasarkan UndangUndang Nomor 8 Tahun 1999 Tentang Perlindungan Konsumen.", Diponegoro Law Journal 5.3 pp. 2-3, 2019.

[2] P. B. Mahargiono and K. E. Cahyono, "Sebagai Dasar Pembenahan FasiltasKontroversi Transportasi Online," Pros. Semin. Nas. Multi Disiplin Ilmu, vol. 3, no. Sendi_U 3, pp. 663-668, 2017.

[3] Kotler, Philip and Gary Armstrong. Prinsip-prinsip Pemasaran. Edisi 13. Jilid 1. Jakarta : Erlangga, 2012.

[4] Lovelock, C, dan John Wirtz,. "Pemasaran Jasa Perspektif edisi 7". Jakarta : Erlangga, 2011.

[5] A. S. Lubis and N. R. Andayani, 
"Pengaruh Kualitas Pelayanan (Service Quality) Terhadap Kepuasan Pelanggan Pt. Sucofindo Batam," J. Appl. Bus. Adm., vol. 1, no. 2, pp. 232-243, 2018.

[6] Zeithaml, V.A., M.J. Bitner, D.D. Gremler. Services Marketing: Integrating Customer Focus Across the Firm 6 thed. Mc.GrawHill. Boston, 2013.

[7] Widodo, Erna, Dan Mukhtar. Konstruksi Ke Arah Penelitian Deskriptif. Avirouz, Yogyakarta, 2000.

[8] Hidayat SyahPenelitian Deskriptif. Jakarta: Rajawali, 2010.

[9] Sukmadinata. Metode Penelitian Pendidikan. Remaja Rosdakarya; Bandung, 2016.

[10] Riduwan. Pengantar Statistik Sosial. Alfabeta. Bandung, 2012.

[11] Indriantoro, Nur dan Bambang Sopomo.. Metodologi Penelitian Bisnis Untuk Akuntansi dan Manajemen. Edisi Pertama, BPFE. Yogyakarta, 2011.

[12] Witarto. Memahami Pengolahan Data. Jakarta: Bumi Aksara, 2008.

[13] Sugiyono. Metode Penelitian Kuantitatif Kualitatif dan $R \& D$. Bandung : Alfabeta, 2014.

[14] Arikunto, S. Prosedur Penelitian: Suatu Pendekatan Praktik. Jakarta: Rineka Cipta, 2013.

[15] Sugiyono Statistik Untuk Penelitian. Bandung: Alfabeta, 2013.

[16] Miles, Matthew B dan A. Michael Huberman. Analisis Data Kualitatif :Buku Sumber tentang Metode-MetodeBaru. Jakarta: Universitas Indonesia Press, 2014.

[17] Aspiani, Pengaruh Kualitas Pelayanan terhadap Kepuasan Pelanggan pada Pengguna Jasa Transportasi Grab Online di Kota Makassar. Diploma thesis, UNIVERSITAS NEGERI MAKASSAR, 2018.

[18] Yovan Sawir Saputra, Shinta Wahyu Hati., "analisis kepuasan pelanggan terhadap kualitas layanan ojek online (wakjek) di kota batam," Journal of Applied Business Administration Vol 1, No 1, pp. 96-121, 2017.

[19] Erlin Setyaningsih, Ego Ismawan2 Taufik Hidayat, Analisa Tingkat Kepuasan Pelanggan Transportasi Online Maxim di Balikpapan, j-sim: Jurnal Sistem Informasi, Vol. 3, No. 1, pp.33-38, 2019. 